\title{
No Easy Walk Through Primary Elections for Rural Women in Zimbabwe
}

\author{
Cowen Dziva ${ }^{1}$, Peter Makaye ${ }^{2}$ and Brian Dube ${ }^{3}$ \\ ${ }^{1}$ (Department of Development studies, Zimbabwe Open University, Zimbabwe) \\ ${ }^{2}$ (Department of Development studies, Midlands State University, Zimbabwe) \\ ${ }^{3}$ (Department of Public Law, Midlands State University, Zimbabwe)
}

\begin{abstract}
This research paper seeks to analyse rural gender imbalances in political participation during primary elections of major political parties in Zimbabwe. The study investigated factors militating against women's active participation in rural party politics, as voters and candidates in Mberengwa rural district. Regardless of the fact that women are the majority, who contribute a considerable share in rural economy, their meaningful participation and representation in decision-making processes is still very low. Rural women face challenges within and outside rural institutions that perpetuate inequality and protect the privileges enjoyed by men. Through secondary data review, as well as primary data collected through structured interviews and participant observations, this research found that the political, cultural, economic and social dynamics like inadequate education, lack of financial resources, cultural discrimination, low self-esteem, political party malpractices among others, account for low political participation of rural women in 2013 party primary elections. In order for Zimbabwe to comply with the constitution and international human rights obligations on improving women's political participation, the paper suggests, inter alia, full implementation of quota systems by parties, intra-party democracy and non-violence, gender-sensitive funding and political education programmes by government, political parties and advocacy NGOs.
\end{abstract}

Keywords: elections, participation, rural women, politics.

\section{INTRODUCTION}

Women entering politics often find an uneven or even hostile political, public, cultural and social environment that deters them from winning. A quick glance at the current composition of political decisionmakers in any political party provides evidence that women still face numerous obstacles in contemporary political landscape in Zimbabwe. Few women hold decision making positions as a result of the playing field existing in most political parties. This is happening despite well-documented efforts by states and non-state actors to ensure political equality between men and women. In Zimbabwe, the imbalance is more rife in rural areas than urban areas as statistics show that women comprised $19 \%$ of urban councillors and $18 \%$ of rural councillors in 2008 (UNDP 2008). While the political playing field in urban and rural areas has its own particular characteristics, one feature remains common to both: it is uneven and not conducive to women's active participation in issues shaping their everyday life. Against this background, this research attempts to answer the following questions: What are the obstacles faced by rural women in political participation during primary elections? How can women better cope with these stoppages? This article is envisaged to take a rung towards increasing rural women's politicking through ascertaining problems they face in political parties. The paper tries to answer the first aforementioned question by grouping factors in socio-economic and administrative/political sets. The paper ends by suggesting strategies which can be adopted by political parties and rural folk as they seek to deal decisively with the question of women participation in rural politics.

Countless research on women participation in politics, Olufemi (2006), Schmidt (1987), Fisher (1997) and Uhunmwuangho (2011) try to grapple with problems faced by women in vying for political positions at parliament and executive levels during general elections. Those who tried to do so in rural Zimbabwe (Mupfeka 2008) however focused mainly on the factors that hinder women councillors from meaningful participation in council proceedings. These scholars failed dismally to note the need to research on women challenges in internal party-elections. Of particular interest, however, is the failure to note that paltry women councillors are a microcosm of the macrocosm challenges that they face in the run to party primary elections. Time and again political parties preach the importance of women participation in politics and presence in local governance, though together with political scientists, have failed to document, by default or otherwise, the causes and consequences of low women participation in Zimbabwe's rural party politics. The country's rural women are systematically marginalized from the drafting, development and implementation of political party policies and many related issues that directly affect their competitiveness with men. This research sought to fill this void by providing vivid evidence on women participation in rural party politics. 
Political participation is the voluntary activities by which members of the society share in the selection of leaders and directly or indirectly in the formation of public policy (Simbine 2006). It is the understanding of this paper that when women participate actively in politics, they will be holding public and party offices, freely voting and be voted in an election. Active participation requires time to attend meetings, vote and inform oneself about issues that affect their community (Makumbe 1996). This participation by all citizens in the management of public affairs is the very temperament of democracy in the contemporary era. Among other democratic values, it promotes transparency, accountability, effectiveness, efficiency which eventually leads to sustainable peace and development. This is why world actors have shown commitment to gender equality and the emancipation of women in all facets of life. Gender equality is reinforced by the Millennium Development Goal 2 target 2 and the Convention on Elimination of All Forms of Discrimination Against Women (CEDAW) and the Beijing Platform of Action, which specifically reiterates that,

"Without the active participation of women and the incorporation of women's perspectives at all levels of decision making, the goals of equality, development and peace cannot be achieved." (UN Women watch 1995).

This means women have the right to public life, which in turn open doors for true sustainable development in rural areas and Zimbabwe at large. In addition, the Universal Declaration of Human Rights of 1948 reiterated in art 25 that every person has a right to:

1) Take part in the conduct of public affairs, directly or through freely chosen representatives;

2) To vote and be elected at genuine periodic elections which shall be by universal and equal suffrage...

These international instruments together with regional human rights instruments such as the African Charter on Human and People's Rights, the Women's Protocol to the African Charter on Human and People's Rights emphasise on the right to vote, the right to stand for election and a general non-discrimination principle in elections as core codes. Gender equality also reinforced by the Zimbabwean constitution that emphasise women participation at all levels. Together, these instruments make room for women as they promote equality under the law.

Against this prodigious commitment, statistics the world over have shown that women are the least represented in parliament, local councils and local governance structures. Women's representation in legislatures and local government around the world was less than 15 percent in 2007 (UNDP Report, 2007).

This is no exception of Zimbabwe, where politics, especially in rural areas remains largely dominated by men at the expense of women. According to ZimStats (2012), women in Zimbabwe constitute $51.9 \%$ of the population yet they are underrepresented in decision-making processes. There is every reason for the nation and community to tape this unutilised human resource for wider development benefits. Women's equal participation in political life plays a crucial role in the general process of the advancement of women and development of a country. If women get the node, benefits will transcend to people in society. Though it has proved difficult to find scientific evidence to prove that women are simply more honest than men (Graff, 2003:11), many strongly believe women to be honest, hence their presence in decision making positions to be reducing rampant corruption in local governance. Thus women's partaking is not just a move to ensure respect of human rights as enshrined in the constitution; that is the right to participate but must be seen as a necessary condition for development. Without the active participation of women and the incorporation of women's perspective at all levels of decision making, the Zimbabwean goals of equality, development and peace cannot be achieved (FWCW, 1995).

\subsection{Study area}

\section{Study Area and Methodology.}

The research was conducted in Mberengwa district in the southern part of Midlands province in Zimbabwe. According to the Central Statistics Office, Mberengwa district covers an area of 5096km2 and has a population of 186 164, of which (99 079) 53.2\% are females (ZimStat, 2012). The district was purposely selected because of its accessibility to researchers and a long history of politics dominated by males. The district has four constituencies, which are Mberengwa South, Mberengwa East, Mberengwa West and Mberengwa North, and is divided in 37 administrative wards, each represented by a Councillor elected by the community through secret ballot. The wards are the creation of the national legislation: the Rural District Council's Act of 1988 Chapter 29:13. Together, the 37 Councillors form part of the Mberengwa Rural District Council (MRDC), a semi-autonomous local governance structure, legally responsible for the planning and implementation of projects in the rural district. Rural District Councils in Zimbabwe are a brainchild of decentralisation drive of 1980 s, with a structure developed with a view to make it easier for grassroots citizens to participate in local governance issues.

Up till 2013, it is a little more difficult for women to enter into local politics as statistics released by Zimbabwe Electoral Commission (ZEC), in accordance with the Electoral Act (Chapter 2:13) on 12 July 2013 shows that male candidates continue to dominate rural councils elections. Mberengwa rural district has a total of 
74 candidates, who won primary elections from Zimbabwe African National Union Patriotic Front (ZANU-PF), Movement for Democratic Change Tsvangirai (MDC-T) and MDC faction held June and May 2013 respectively. These are battling it out to represent respective wards in Mberengwa council on 31 July 2013 harmonised elections. Women are underrepresented, as they represent $20 \%$ of the 74 candidates who passed Nomination court (See Fig.1). There is a possibility that the percentage will decrease after the general elections, as majority women face obstacles to outwit male opponents.

Fig.1. Candidates for 312013 Council Elections in Mberengwa district

\begin{tabular}{|l|l|l|l|l|}
\hline Sex & All candidates & ZANU PF & MDC-T & MDC \\
\hline Males & 59 & 30 & 28 & 1 \\
\hline Females & 15 & 5 & 9 & 1 \\
\hline Totals & 74 & 35 & 37 & 2 \\
\hline
\end{tabular}

Source: Zimbabwe Electoral Commission, July 2013.

\subsection{Methodology}

The study adopted a case study method whereby Mberengwa West constituency was selected to come up with a close analysis of the situation, so as to give a corpus view of women challenges to active political participation. Of all the four constituencies, Mberengwa West and North share the lowest number of women candidates to have passed the primary election phase. In this case, Mberengwa west constituency is selected ahead of Mberengwa North because of its accessibility to the researchers. The constituency has got 8 wards which are as follows; ward 13,14,29,30,31,32,33 and 34 to be represented by 8 councillors. The constituency has seen men dominating politics from all political divide. An effort by paltry women to contest in 2013 primary elections has not changed the situation as men come out as the outright winners to represent parties in general elections. Out of the 17 councillors who won MDC-T and ZANU PF primary elections in the constituency to contest in final elections, only 3 are women from ward 13, 33 and 34, a clear indication of the need for investigation.

Primary data for this research was mainly gathered through cell-phone and structured face to face interviews with 20 women, including contestants for council primaries and those in local and party leadership from all political divide to get vivid evidence on the obstacles they face during primary elections. The interview methods were very essential as they allowed women to express themselves fully and without fear as issues of politics are always viewed with suspicion especially in the run up to an election. Above all, interviews with community women allowed for candid talk, as it permitted development of dialogue between the researchers and the respondent, thereby creating a more natural form of exchange which allowed the respondents the freedom to express their views more meaningfully. In-depth interviews with male electorates and traditional leadership conveniently selected in the constituency prompted them to express freely about what they thought of voting women candidates in politics. The interviews were conducted exclusively in Shona and Ndebele which are local languages spoken in Mberengwa West, so as to enhance the understanding and accuracy of the results. This research also utilized participant observations during party-political meetings in the run to and during primary elections and at social gatherings in ward 14 and 33. This was an essential means of observing the attitude and involvement behavior of both rural women and men. This method also helped in ascertaining society's attitude towards women candidates in politics. Those who participated in the study represented a range of socio-economic backgrounds in the hopes of rendering the study more representative of a typical rural Zimbabwean society. More women than men were sampled for the simple reason that the issue researched has more to do with them. Respondents were assured of the confidentiality and were encouraged not to identify their names. In addition, primary data was backed by secondary data review from published books, political party reports, research works, journals and newspapers on women in politics.

\section{Results And Discussion}

\subsection{Socio-economic obstacles to women's active participation in primary elections}

Women in Africa face large scale discrimination from both men and their fellow women in trying to venture into politics. The political field is viewed as men's domains in many Zimbabwean societies. More often than not, men constitute a larger percentage of party's membership and this tends to affect women when it comes to selecting or electing candidates for primary elections. Nadezdha (1998) noted that men dominate the political arena; men formulate the rules of the political game; and men define the standards for evaluation. This is furthered by the patriarchal society context in rural Zimbabwe, where men are regarded as decision makers, whereas persuading the electorate to vote for female candidates has yielded little results (Tsanga 2002).

Therefore, for women candidates to breakthrough, you need to have strong ties with the top brass, some which includes offering them sexual favors, a myth which explains why $96 \%$ of the candidates who contested council primary elections are unmarried. 
Cultural values and religion in rural Zimbabwe also relegate women to a peripheral position in society. Similarly, in Northern Nigeria there is the purdah system (i.e. house seclusion of women), which segregate women and discourage them to take part in politics (Attoe, 2002). Religion therefore in most cases keeps women in perpetual servitude, domination, and slavery as they have sexist and patriarchal values in structure and character, which perpetually seek to subjugate women. Respondents' religious affiliation in Mberengwa west shows that about $50.2 \%$ are Christians, $30 \%$ traditionalists and $19.8 \%$ for various religions. Research found only Jehova's Witness (Watch Tower) church to be retraining women participation in politics. Even though Christianity and other religions does not directly refrain women participation in politics, all of them call for men's absolute domination and restrict their movement around especially at night, for it is abomination. As a result, woman who play roles in public life in rural Zimbabwe have to endure challenges that have very little to do with their ideas. As noted by ward 14 Councilor,

"People tend to focus on candidate's personal life, such as womanhood, marital life and alleged personal escapades, instead of celebrating and encouraging her as the only one woman who at least has a voice in matters that shape our everyday rural life"

Women are jealousy of each other and they join the fray in waging acerbic attacks on fellow women in public life. Magaisa (2009), noted with grave concern that the ammunition of choice is targeted not simply at her ideas - it often rounds on her person, on how many children she has outside marriage, on her singlemotherhood status, on the alleged numbers of her sleeping partners, real or imagined. This is, however, different when it comes to male candidates, whom people tend to direct their aspersions on the reproductive organs of the candidate's mother, wife, sister, his grandmother, or even his daughters, and not about the man himself. It is this character assassination which derails the confidence and self-esteem in women candidates and their supporters, thereby leaving few women activists, who are in most cases widows and divorcees competing while for the majority politics is still a hard rugged road for men to venture.

Lack of constituency is a social depravity impeding women participation in rural politics. Razia Faiz was quoted by Nadezdha (1998) to have regarded this as the "most overwhelming obstacles for women in entering parliament and local government..." Though this seems to be affecting even urbanites, rural candidates are affected most. This is probably so because rural areas are an epitome of cultural norm and values. More so, it is very difficult to identify one as alien in urban areas, than it is in rural areas. Women move from their father's home to their husband's home; their in-laws home, where they are not popular and are seen as refugees. According to Razia Faiz, they have no base from which to develop contacts with the people or to build knowledge and experience about the issues..." (Nadezdha 1998). Given the importance attached by electorates in voting for someone who grew up in the community, this posed a serious hurdle for Mberengwa rural women candidates during primary elections. This is coupled by the fact that rural politics is divided according to castes, tribes, church denominations and political factions, which make it difficult for them to collaborate for one cause. The above sentiment was also echoed by Dunne (2003), who noted voting to proceeds largely on the basis of tribal affiliation where electors are likely to vote on their tribal or religious affiliation rather than follow a political ideology or issue specific platform. This being the case, lack of constituency is a blow to rural women who end up sheering away from political participation as candidates.

Lack of adequate education is also hindering the participation of rural women in politics. Rural women constitute a larger ratio of the illiterate group in Sub-Sahara Africa. Research has found two-thirds of the approximately 880 million illiterate adults in the world to be women; 60 percent of the 135 million children in the world between ages seven and eighteen who are not receiving education to be girls (Negash, 2006) Like in the pre-colonial era, few Zimbabwean women are educated as compared to their male counterparts and this militates against their participation in rural politics. This scenario can, however, be attributed to the fact that in most families, parents and guardians prefer to send their sons to school, instead of their daughters whom they know will eventually get married and thus get incorporated into another family. Consequently, a larger percentage of rural women remain uneducated and incapacitated to actively participate in politics. Educational level of women respondents shows that $4 \%$ attained tertiary education certificates, $16 \%$ had secondary school certificate, $70 \%$ had primary/standard school certificate while $10 \%$ did not attend any formal education. Most interviewed vanquished women candidates for Council elections lament to have not received formal education and accuse their male counterparts to have used that weakness to counter them during campaigns. Ward 14 candidate for ZANU PF also confirmed education to be pivotal for one to be voted,

"It is very difficult to win elections if you are illiterate. Competitors will go around de-campaigning you, telling electorates that you will not be in a position to effectively represent them given that council proceedings, memos and minutes are written in English. Also, you must be literate to read newspapers and reports to be abreast of development events. So, if you are illiterate, then people will not vote you". 
For rural women in Mberengwa, illiteracy proved a double blow as aspiring candidates were misconstrued with facts about primary elections and party guidelines. Consequently, many women candidates claim to have withdrawn their candidatures after the literate misinterpreted guidelines to them.

Poverty and unemployment further impedes women political participation in rural Zimbabwe. According to United Nations statistics, 1.3 billion persons in the world live in poverty and 70 per cent of them are rural women (Nadezdha 1998) in Sub-Sahara Africa. It is difficult for rural women to participate in political life when their major concern is survival. In that scenario, women have no choice but to spend much of their time and meager resources to fulfill the basic needs of families. About 80 percent women interviewed for this study, it is useless and unreasonable to go about political rallies, campaigns and voting whilst their families are hungry. The majority interviewed spends their time in community gardens, fields, gold panning to generate income for the survival of their families. As less than $20 \%$ of women are in paid employment in Sub-Saharan Africa (UN 2008), coupled with reduced government spending on social services, women are burdened more by poverty. This leaves paltry employed women joining the political game since they will be in a position to balance family upkeep and political life. This is why Nadezdha (1998) saw it fit to say the social and economic status of women in society has a direct influence on their participation in political institutions and elected bodies.

Poverty is compounded by lack of financial support from party and donors to hinder effective female participation in politics in rural Zimbabwe. Funding is needed by candidates for rolling out effective campaigns, family upkeep and the welfare of campaign aides. Farzana (2005) was right to view politics as a game increasingly becoming commercialized. As one responded noted,

"Politics is for pensioners with livestock to sell, not the young ones who live from hand to mouth. What will you give people? ... By the time of general elections come you will be broke and commit suicide after losing. Also if don't concentrate on working in your field doing politics, your family will be food insecure"

This deters most rural poor young woman from participating since a large portion of them are not as financially strong as their male counterparts. The historical imbalance between men and woman continue to permeate in society, thereby limiting women access to rural factors of production and information and thus keeping them in an inferior status than men. Women's unequal access to and control of resources and productive assets is therefore at the heart of their low political participation.

Rural women are also burdened with reproductive and productive roles to participate, contest and win primary elections. Family responsibilities and childbearing hinder women from participating effectively in strenuous partisan political activities. Nadezdha (1998) has it that in majority of countries, rural women's unpaid labour activity is twice that of men and the economic value of women's unpaid labour is estimated to be from 10 to 35 per cent of the world's GNP (or US\$ 11 trillion). During a sizeable part of their adult lives, most women are involved not only in child bearing, but also in child rearing, household chores and looking after the sick.

Matters for rural political candidates in rural Zimbabwe were worsened by the fact that primary elections for both MDC-T and ZANU PF parties were conducted during the harvesting time, when people were concentrating with removing crops in fields. Married women also confirmed that, political gatherings participation in the run to primaries was also relegated to men as women spent most of their time in the fields.

Furthermore, the demand for women as wives, mothers, and home keepers, leave them with little time and energy to partake in political meetings and campaigns, which unfortunately take place at very odd hours and with no strict compliance to time (Duke, 2005). As a result, women are overstretched and overworked by dual roles which give them little time for rigor campaign, thereby loosing elections.

\subsection{Political and administrative obstacles to women's active participation in primary elections.}

Zimbabwean politics is referred to as a very "dirty game' characterized by violence, abductions and killings of adversaries during election time. This unfortunate phenomenon, curiously gained ascendancy in a number of primary party elections in Zimbabwe and serves as a strong deterrent to the full participation of female candidates, who are generally considered to be the weaker sex on account of their physiological makeup. Inquisitively, even where women do not feature as candidates in elections, armed thugs and other politicalgangsters target women for rape, torture, and murder as the expression of their discontent with election proceedings or outcomes (Farzana, 2005). Primary elections for ZANU PF and MDC T parties in Mberengwa district 2013, ahead of the July 312013 Harmonized Elections were shambolic characterized with factionalism, direct, indirect violence and threats for violence. MDC women members and their sympathizers in Mberengwa are perceived opponents of the rural dominant ZANU-PF, and associating with MDC movement attracts discrimination and all sorts of violence. This leaves man male members of the MDC free-riding. Therefore, violence and lack of internal party democracy, together with other factors together combines to scare women and provoke their fears of losing loved members of their families, all of which militates against their objective politicking. 
Despite the fact that Zimbabwe has least 18 pieces of legislation that seek to enhance the status of women, the lack of specific legislative provisions on quotas is a barrier to the increased representation of women in elective positions. The constitution and electoral laws of Zimbabwe and political parties are silent on quotas to advance women participation in rural politics. Political parties in Zimbabwe have chosen to pay lip service to women quotas and the SADC 50/50 representation principle. Results for the Council primary elections conducted in Mberengwa district by ZANU PF and MDC-T show low women participation of $14.2 \%$ and $23.3 \%$ respectively (ZEC 2013). Thus primary elections in rural Zimbabwe have shown that putting women quotas into practice largely remains between a dream and a nightmare. Many respondents took turns to blame the short notice to conduction of the 2013 primary elections, which did not give room for policy implementation. For instance, ward 14 in Mberengwa west is reserved for a women councilor by ZANU PF, but a man contested her even though in vain.

Electoral systems and procedures of ZANU PF and MDC-T in 2013 affected women participation. The process of selecting candidates within political parties is just as important, and perhaps even more important for inclusivity than the type of electoral system at national level (Molokomme 1999). The processes are dominated by elites, traditional leaders and have got procedures which see many, women in this case failing to make it.

Salih (2006) elaborates on some main challenges confronting internal party democracy in Africa, to include the dominance of elites, non-competitive leadership elections, discriminatory selection of candidates, and clientelism. The primary elections for both ZANU PF and MDC were characterised by controversial disqualifications, impositions of candidates, poor logistics, lack of information, shortage of ballot papers, attempts to run-away with ballot boxes, delayed announcement of results and allegations of rigging. Few women also mentioned the inability to acquire a national Identity documents as their reason for not participating.

Moreover, respondents view the ward-based electoral system as highly competitive and does not easily allow for winning of party primaries by women. These loopholes to internal democracy saw many women councillors failing to win the primaries. It is therefore important that selection procedures within parties be as inclusive, transparent and democratic as possible.

\section{Confronting The Problem: Some Recommendations}

Insignificant attention has been devoted to examining the factors that hinder rural women in internal party politics despite this being a common problem in rural party politics. Lack of women participation in primary elections is not only an infringement to their rights and a blow to internal party democracy, but a threat to community and national development.

Against this background, there is an urgent need to seek permanent and lasting solutions that will improve women participation and winning of primary party elections in rural Zimbabwe. In this present study, the preferred solution, ranked by respondents in terms of effectiveness was to ensure economic stabilisation and that women approach men in levels of literacy, workforce participation and university education and thus become men's equals in social spheres. This will make women to be seen likely as men's equals in the political sphere and therefore their representation will increase. More so, promotion of women education will also increase prospects to for better employment opportunities. Considering that one characteristic of development that has proven particularly important for women's representation in Western countries is higher rates of women's participation in the labour force (Anderson, 1975; Welch, 1977; Togeby, 1994), Zimbabwean women will procure the same, for moving out of the house setup into the workforce is said to have consciousnessraising effect on women. Such an environment will mentor women to become politicized through taking part in labour unions and professional organizations to defend their rights.

There is need for Zimbabwean government and NGOs to join hands and forge partnerships that will come up with educational curriculum and professional trainings for capacitating and orienting young women in political life and men to accommodate women. In that way, women work harder and cover the gap through being equipped with skills on how to negotiate and enter the spaces dominated by men. The trainings should embrace the fact that women are very good campaigners, organizers and support mobilizers, but fear sometimes prevents them from contesting elections and from participating in political life. This could be accomplished by seeking donor funding to support women willing to venture into politics. The media should also play a role a crucial role to tell stories about successfully women politicians, rather than coverage on fashion competitions and movie stars that hardly promote women's sense of self-worth and self-respect let alone encouraging them to take on positions of public responsibility. This will increase the pool of women ready for recruitment in rural political life where there is need.

All of these important measures should be complemented by ensuring that political parties exercise intra-party democracy during the conduct of their primary elections, to ensure better representation for women through affirmative policies. The political parties should religiously follow the clear stipulated democratic principles in their constitutions, and shun away malpractices as shown in 2013 ZANU PF and MDC-T primaries 
characterised with lip service to quota system, rampant violence, vote buying and rigging. One interviewed women reiterated that,

"If only primary elections were done free and fair, without intimidation and within a reasonable time frame, I was going to contest and win resoundingly ..., but I and my family fear shame and reprisals."

There is also need for ZANU PF and MDC parties to adopt good types of electoral systems that ensures women to freely and secretly express themselves. Most in interviewed women were disgruntled with the shambolic way in which the ZANU PF primaries were conducted, leaving no secrecy at all.

Using the new constitution signed into law on May 222013 as their weapon, women rights activists and NGOs should advocate and lobby for equal women representation. Quotas through political parties have been successful in the Scandanavian countries (Denmark , 34\%, Norway,34\% and Sweden, 40\%, Finland,38\%, and $25 \%$ in Iceland.), not because of law demands but due to sustained pressure on the part of women's groups within parties as well as the women's movement in general. Conceivably gender activists should not just push for numbers but also evaluate the conduciveness of the environment for women in politics to freely participate. Interrogations should be done on whether these women are free to become actual decision makers or mere cheerleading implementers of policies still crafted by males (Forokah 2013).

\section{Conclusion}

Even though women comprise the majority of the world's population and contribute immensely to rural productive and production work, they have largely been excluded from political life and decision making processes as shown during the primary elections in Mberengwa district. As a result, Zimbabwe like many signatories will not meet the target of having at least $50 \%$ representation of women in decision-making positions by 2015 as called for by the SADC Protocol on Gender and Development signed in Johannesburg in 2008.

Results from the party primary elections are showing that Zimbabwe is likely to transgress from the $200819 \%$ mark of women in councils, as the present percent for women candidates for councilors in Mberengwa district is at 20.2\% (ZEC 2013) before the general election slotted for 31 July 2013. Women participation is militated by a combination of political, economic and socio-cultural barriers which deter women from public life. The relatively high level of illiteracy, low self-esteem, patriarchal society, poverty and lack of party and government support, the high incidents of political motivated violence serves as stabling block in ensuring the participation of women in issues shaping their everyday life.

Rural women's political participation is largely dependent on structural factors such as the overall development of Zimbabwe, the number of employed women and literacy levels. This together with the democratisation of internal party politics in Zimbabwe, electoral reforms, capacity building of political candidates and awareness campaigns will improve women participation in all facets of life. All these efforts should be a community-centred approach, whereby there is direct involvement of the rural women, the rural men and political parties. Such initiatives are will bring about positive results in terms of curbing acerbic attacks on women and promoting women participation as candidates in intra party elections.

\section{References}

[1] Anderson. K, "Working women and political participation, 1952-1972", American Journal of Political Science 19: 439-453, 1975.

[2] Attoe, S. A, "Problems Militating against Women in Politics", 2002. www.nigeriaonline.com/links/send.asp?blurb+151 on the $7^{\text {th }}$ of July 2013.

[3] Duke. J, The Dynamics of Women Participation in Democratic Politics and Sustainable Development in Africa, Journal of Sustainable Development in Africa (Volume 12, No.4, 2010), Clarion University of Pennsylvania, Clarion, Pennsylvania retrieved from http://www.unpac.ca/wagegap4.html on the 1st of September 2011.

[4] Dunne. S, Hashemite Kingdom of Jordan: Needs Assessment Mission, United Nations, Unpublished, 2007.

[5] Fisher. R, Let the People Decide: Neighborhood Organizing in America. 2nd Edn, Twayne Publishers, Twayne, New York, 1997.

[6] Forokah. N, Power hunger too strong for SADC quotas to work, June 10 2013. http://www.sokwanele.com/power-hunger-toostrong-sadc-quotas-work/10062013.

[7] Graff. I, Invisible Women, Invisible Rights: Women's Right to Election Participation with a Case Study of the 2001 Local Elections in Pakistan. Oslo, University of Oslo,Dept of Public and International Law, 2003.

[8] Griner. S, and Zovatto, D (eds), Funding of Political Parties and Election Campaigns in the Americas San José: OAS and International IDEA, 2005.

[9] Makumbe. J, Participatory Development, University of Zimbabwe Publications, Harare, 1996.

[10] Magaisa. A, Politics and prejudice: plight of Zimbabwean women, $2009 . \quad$ Accessed from http://www.newzimbabwe.com/pages/magaisa94.18710.html on 20th June 2013.

[11] Molokomme, A. "Building Inclusiveness in SADC's Democratic Systems: The Case of Women's Representation in Leadership Positions" Paper presented at the Southern African Elections Forum, Windhoek, Namibia, 11-14 June 2000.

[12] Nadezdha. S, Women in Parliament, Stockholm Women in Parliament: Beyond Numbers, Stockholm, International IDEA,1998 retrieved from (http://www.idea.int) on the $30^{\text {th }}$ June 2013.

Negash. A, "Economic empowerment of women" 2006. Accessed from http://www.scu.edu/ethics/practicing/focusareas/global_ethics/economic-empowerment.html on the 5th of June 2013.

[14] Olufemi. O, Democracy and Development Joja Educational Research and Publishers Ltd., Lagos, 2006.

[15] Razia. F, in Nadezdha S, Women in Parliament, Stockholm Women in Parliament: Beyond Numbers, Stockholm, International IDEA, 1998. Accessed from http://www.idea.int on the $30^{\text {th }}$ June 2013. 
[16] Salih. M.A and Mohamed. A, 'The Challenges of Internal Party Democracy in Africa' in UNDP, A Handbook on Working with Political Parties, pp.54-5. New York: UNDP, 2006.

[17] Schmidt.S.N, Management, Women in Management-Threat or Opportunity Instructor's Film Guide, 1987.

[18] Togeby. L, "Political Implications of Increasing Numbers of Women in the Labor Force", Comparative Political Studies 27:211240,1994

[19] Tsanga. A.S, A critical Analysis of Women's Constitutional and Legal Rights in Zimbabwe in Relation to the Convention of the Elimination of All Forms of Discrimination Against Women," Maine Law Review, Vol 54, no 22002.

[20] Uhunmwuangho S.O, Problems and prospects of women participation in Nigeria politics: 21 stcentury as a focus. International Journal of Humanities, 3(3): 45-53, 2011.

[21] Welch. S, "Women as Political Animals? A test of some explanation for male-female political participation differences." American Journal of Political Science 21:711-730, 1977.

[22] UNDP, Human Development Report, 2005. Accessed http://www.un.org/womenwatch/daw/followup/session/presskit/fs $1 . h t m$ on the $9^{\text {th }}$ of July 2013.

[23] UNDP, Fast facts: Millennium Development Goals,Zimbabwe, 2008. Accessed from http://www.mdgs.org.zw//reports/MDGFsheet3.pdf on 15 July 2013.

[24] UNDW, The Role of Women in Public Life. New York: UNDAW, 1991.

[25] UNWW, Beijing Declaration and Platform of Action, The Fourth Women Conference on Women, Beijing, 1995. Accesed from http://www.un.org/womenwatch/daw/beijing/pdf/BDPfA\%20E.pdf on 28 July 2013.

[27] Zimbabwe National Statistics Agency, 2012 Census: Preliminary Report, Harare, 2012.

[28] ZEC, Electoral Notice according to Electoral Act (Chapter 2:13), Local Authority Elections 31 July 2013, Results of Nomination Courts, in Daily News July 122013. 